\title{
Sociolinguistics Inputs and English as Second Language Classrooms
}

\author{
Ofodu Graceful Onovughe ${ }^{1}$ \\ ${ }^{1}$ Institute of Education, Faculty of Education, Ekiti State University, Nigeria \\ Correspondence: Ofodu Graceful Onovughe, Institute of Education, Faculty of Education, Ekiti State University, \\ Ado-Ekiti, Ekiti State, Nigeria. E-mail: ofodugraceful@hotmail.com
}

Received: April 24, 2012 Accepted: June 7, 2012 Online Published: July 9, 2012

doi:10.5539/elt.v5n8p157 URL: http://dx.doi.org/10.5539/elt.v5n8p157

\begin{abstract}
Sociolinguistic inputs in language acquisition and use of English as Second Language in classrooms is the main focus of this study. A survey research design was adopted. The population consisted of all secondary school students in Akure Local Government of Ondo State, Nigeria. Two hundred and forty (240) students in senior secondary school classes were deliberately selected from six secondary schools randomly sampled. A fourteen-item questionnaire designated to elicit the required information on the sociolinguistic inputs was used for data collection. The face and content validity of the instrument was ensured. A trial test of the instrument was carried out with students in a community senior secondary school in Ekiti State. Split- half reliability was used and a reliability coefficient of 0.9 was obtained. One way Analysis of Variance (ANOVA), t-test and Pearson Product Moment correlation statistics were employed for the data analysis. Findings revealed that parents' occupations have significant impact on secondary school students' use of English. Results also revealed that gender, age and religion have insignificant input on secondary school students' use of English. It was concluded that the family still remains a major source and most potent place for language learning; therefore, parents should give more attention to students language use at home and provide all the necessary impetus.
\end{abstract}

Keywords: inputs, ESL, sociolinguistics, age, class levels, parents' occupation

\section{Introduction}

Research has established the place of social interaction, social activity and social context in language acquisition (Vygotsky, 1978). Language is one of the potent weapons of any progressive society. The society is made or marred by the roles played by the communicative skills and imperatives of the available languages in a society. The descriptive study of the effect of any and all aspects of society, including cultural norms, expectations, and context, on the way language is used is called sociolinguistics. It is the overall effect of the society on language use. It also studies how language varieties differ between groups separated by certain social variables, for instance ethnicity, religion, status, gender, level of education, age, etc., and how creation and adherence to these rules are used to categorize individuals in social or socioeconomic classes. As the usage of a language varies from place to place, language usage also varies among social classes.

In Nigeria, the place of language in the entire social structures cannot be glossed over. The Federal Government of Nigeria (2004) in its national policy on education states that in appreciating the place of language as a means of promoting social interaction, national cohesion and preserving cultures; every child shall learn the language of the immediate environment and one of the three Nigerian languages, in addition to English and French which is recognized as the second official language. This shows that learners are encumbered with a lot of language overload.

The English language is the most widely used language in all sectors of the country especially on official basis. It is a significant factor of national unity. In addition, the society expects students at all levels to be able to speak the English language meaningfully and intelligently. In addition, credit pass in English is a compulsory requirement that all candidates are required to get before they could be admitted into the universities. Hence, to ensure effective learning and acquisition of the English language, it becomes a compulsory subject at all levels of education in Nigeria. The English language has become the language that determines the progress that students can make in their quest to acquire higher education and prestigious employment.

As a multi lingual and multi ethnic country, Nigeria has many languages, some of which have no standard orthography that can be used to perform national linguistic functions. Therefore, English language has an edge 
over all the indigenous languages in Nigeria and its usage cannot be overemphasized.

Although, the study of language cannot be divorced from the study of social identity, thoughts and culture, the main point of departure from modern linguistics is the relevance of language to the understanding of culture and vice versa. However, sociolinguistics attention emphasizes that in so many parts of the world, not only is there very many languages within given national boundaries but also, there exist several varieties of these language, in which, Nigeria is not an exception.

Moreover, sociolinguistics explores the difficulties and considerable interests involve in assessing the relative values of different functions performed by language. These functions are by no means necessarily always headed by that of intellectualization. Invariably, speech has a social function both as a means of communication and as a way of identifying social groups. Hence, to study speech without reference to the society, which uses it, is to exclude the possibility of finding social explanation for structures that are used in utterances. The language of instruction and interaction in the classroom is the English language. The ability of students to communicate verbally cannot be divorced from their sociolinguistic backgrounds. The sociolinguistic background of a student provides him an opportunity of being better or less equipped in oral communications. This is because there are instances of linguistic interference in the language usage of the student.

Observation and research have supported the fact that when students communicate in English, the fluency is obviously absent. There is linguistic interference of the mother tongue in students' utterances and this affects their mastery of English language as a second language (Afe \& Afe, 2005). Various reasons have been advanced for this anomaly. Teachers' attitude and methods of teaching have been lambasted (Adegbile, 2002; Kolawole, 2005; Ofodu, 2009), students' poor attitude to reading, learning and teaching have been not been spared, without much limelight on the impact on inputs such as religion, gender, age and class levels.

The sociolinguistic background of a child influences the child's understanding and speaking of English language in the classroom and school environment. For instance, a child from the high social class whose parents more often than not, use the English language for interaction will have little or no problem in communication with English language in the classroom situation (Omowa, 2012).

On the other hand, a child from the low social class who is used to speaking indigenous language with little or no English language finds it strenuous and unpleasant speaking the English language in a classroom situation during the teaching - learning process.

The family is an important background to the linguistic development of a student's English language. There is the derivation that the social stratification and social mobility of parents help to encourage or discourage students' communication and classroom experience especially during the teaching - learning process.

The ability of the child to utilize the classroom language cannot be separated from his linguistic background, as the family is the agency that socializes the child primarily. The type of socialization given to the child with the language orientation, exhibits the socio-economic background of the family.

Research by Adeyemi and Kalane (2011) asserted that a large number of students are disadvantaged in the learning process because of socio-economic factors or home background. They added that students from these backgrounds have no access to television, computers and other technological gadgets to aid their learning. Even at school, many are ill-motivated and learn the language only to pass their examinations. This most often result in both teachers and students resorting to code-stitching which hampers effective communication in the target language (Adeyemi \& Kolane, 2010).

Bamisaye (2006) is of the opinion that the middle class demonstrates an elaborate linguistic code, facilitating the verbal development of subjective intent and sensitivity to the implication of separateness and differences, providing a complex conceptual hierarchy for the restricted code of the lower working class is distinguished by the rigidity of its syntax. The limited use of appropriate syntax in a teaching-learning process by a student is traceable to the influence of the socializing agents in the domain of the students.

Some specialists in language acquisition claim that the sooner a child starts to learn a second language the better. It certainly seems to make sense that the earlier you start, the longer you will have to learn, and the more progress you will make compared with someone who started later. However, there is evidence that this is not the case, particularly if the second language comes to take the place of the first language, which has never been allowed to develop properly. Some others claim that age is not detrimental to language learning and people of any age can be accomplished language learners.

On the factor of age and second language acquisition, research has revealed that age is an important factor in language learning. Language acquisition depends on a number of hypotheses. The critical period hypothesis is 
one of the prominent hypotheses. This hypothesis is premised on the belief that there is a certain age during which learners can acquire a second language easily and achieve native-like competence. Proponents of this theory explained that the difficulty of acquiring first language after puberty is based on neuropsychological factors. The sensitive period hypothesis has been sometimes used as an alternative term to the critical hypothesis means that certain periods are naturally suitable for the development of each of the aspects of language components (Lenneberg, 1967, Patkowski, 1980). This simply implies that parents and all care givers must harness the pearls of this sensitive period to assist children in their language learning abilities. Failure to do so could affect such children's phonologically, syntactically, semantically, morphologically and pragmatically.

Another hypothesis is the notion of neurophysiology. This theory addresses the lateralization of the brain. The brain has the capacity for language development at a certain period which humans undergo unconsciously and their brains lose plasticity and at such age certain linguistic features cannot be mastered (Ellis, 1994). Neurologically, losses of plasticity or lateralization and cerebral maturation which occur at certain ages have been proved to affect learners' abilities to acquire both pronunciation and grammar (Akinwamide, 2012). It can be said therefore that the earlier children are exposed to a second language the better. Matsuoka and Smith (2008) assert that it is generally believed that children enjoy an advantage over adults in language learning because of their plasticity.

Psychologically, children' language acquisition are affected by their ability to reason, engagement in intellectual activities, motivation and affective factors. Children are strongly motivated to learn a first and second language than adults because they have less anxiety about communicating in a second language.

The place of gender in language learning cannot be ignored in second language learning. Studies have supported that female students mainly use a system that is based around memorizing words and associations between them, whereas boys rely primarily on a system that governs the rules of language (Melville, 2006). Although researchers have long agreed that girls have superior language abilities than boys, until now no one has clearly provided a biological basis that may account for their differences which suggest that language processing is more sensory in boys and more abstract in girls -- could have major implications for teaching children and even provide support for advocates of single sex classroom.

Religion is a major factor in education. Many school age children are sometimes deprive of education because of the belief that Western that would culminate in learning a second language. This attitude could either make or make such pupils.

This study is therefore to investigate the influence of socio-linguistic inputs in English as Second Language classrooms. These sociolinguistic inputs have been claimed to have great impact on learning English as Second Language but the claims have been inconclusive, hence the need for this study.

\section{Materials Studied}

Shaibu and Ahmed (2009) in their study on the implication of gender imbalance in the teaching and learning of English Language on the achievement of the Millenium Development Goals (MDGs) in Nigeria found that for a developing country like Nigeria to achieve the MDGS, much is required most especially considering the time frame set up to achieve them and the nature of commitments of the people towards issues that border collective interests. A questionnaire was administered on 800 female students in secondary schools eliciting their views about the factors responsible for their poor learning and poor performance in English language. The data collected was analyzed using chi square statistics and the outcome revealed that gender characteristics and attitude of the female towards the language influenced greatly their performance. The implication of the outcome to the promotion of gender equality and empowering the woman among other things was that if the female students in the secondary schools cannot perform well in English language, it implies that they cannot learn the various subjects in the curriculum well, because English is the vehicle for learning of all subjects in Nigerian schools. In addition, credit pass in English is a compulsory requirement that all candidates are required to get before they could be admitted into the universities, hence it implies that most female students cannot be admitted into the universities, and this further implies that the number of women required to participate actively and meaningfully in all spheres of the economy can now be few. This is an important challenge to the achievement of MDGS and therefore it was recommended that urgent steps should be taken to overcome this situation if the nation wants to promote gender equality and empower the woman.

Babalola (2010) investigated language learning between male and female students in a subset of Nigerian multilingual society. Through experimental procedures of lecture, discussion and audio-tape mediated discussion a package of linguistic input was adopted. The sample was 240 students in senior classes. The outcome of the investigation revealed that gender had no influence on students' ability to acquire the tools of language of 
communication. The implication is that both male and female learners of English have equal chance of learning and acquiring tools of language.

Ofodu and Babatope (2010) evaluated the segmental and suprasegmental skills of students in a tertiary institution in Nigeria. Using a questionnaire, data was collected from 191 students who were randomly selected. Findings revealed that gender had no influence in students' knowledge of segmental and suprasegmental skills.

Research by Burman, Booth and Bitan (2008) suggest that language processing is more sensory in boys and more abstract in girls -- could have major implications for teaching children and even provide support for advocates of single sex classrooms. Using functional magnetic resonance imaging (fMRI), the researchers measured brain activity in 31 boys and in 31 girls aged 9 to 15 as they performed spelling and writing language tasks. The tasks were delivered in two sensory modalities -- visual and auditory. When visually presented, the children read certain words without hearing them. Presented in an auditory mode, they heard words aloud but did not see them. Using a complex statistical model, the researchers accounted for differences associated with age, gender, type of linguistic judgment, performance accuracy and the method -- written or spoken -- in which words were presented. The researchers found that girls still showed significantly greater activation in language areas of the brain than boys. The information in the tasks got through to girls' language areas of the brain -- areas associated with abstract thinking through language. And their performance accuracy correlated with the degree of activation in some of these language areas. To their astonishment, however, this was not at all the case for boys. In boys, accurate performance depended -- when reading words -on how hard visual areas of the brain worked. In hearing words, boys' performance depended on how hard auditory areas of the brain worked (Burman, Booth \& Bitan (2008)).

Eliot (2011) asserts that although there is no doubt that boys and girls have different interests which shape how they respond to different academic subjects, neuroscientists have had great difficulty identifying meaningful differences between boys' and girls' neural processing -- even for learning to read, which has been the most studied to date. And although research shows that men and women -- not boys and girls -- tend towards different self-professed learning styles, there is no evidence that teaching specifically geared to such differences is actually beneficial.

Matsuoka and Smith (2008) examined age effect on second language acquisition and discovered that age has been regarded as an important factor in acquiring second languages successfully as well as in acquiring first language. In this review article, previous studies regarding age and language acquisition are examined, and the ways in which age may affect the process of acquiring a second language are discussed. For instance, some previous research (e.g. Johnson \& Newport, 1989) evidenced the strong negative correlation ( $r>/-7 /$ ) between age of acquisition / arrival and accuracy or native-like proficiency, which means the younger learners are, the more native-like they become. This correlation supports the critical period hypothesis. Some studies have revealed that adult learners whose age of acquisition/arrival is after puberty are not successful in acquiring a native-like proficiency in a second language, which again supports the critical period hypothesis; whilst other have shown cases where adult learners reached a native-like proficiency, thus refuting the critical period hypothesis. Finally, some pedagogical implications are drawn, using previous interdisciplinary studies in areas such as neuropsychology and phonology. These implications may help adult learners wanting to enhance their proficiency in second language.

Osakinle (2007) in her study found that age had significant influence on adolescents' knowledge and practice while location (rural and urban) had no impact on knowledge and practice of adolescents. Ilugbusi, Falola \&Daramola (2007) examined the relative effects of demographic variables on age and found that age had influence on level of students' level of anxiety. Babatunde (2008) investigated the demographic variables of gender on students' occupational preferences and found that gender and school (rural and urban) had no effect on motivation. Ilugbusi, Falola \&Daramola (2007) examined the relative effects of demographic variables of students' gender and found no significant effect on student- teachers' level of anxiety.

\section{Methods}

A survey research design was adopted. The population of this study consists of all secondary school students in Akure Local Government of Ondo State. The sample was two hundred and forty (240) students in senior secondary school classes selected from six secondary schools randomly. The senior secondary school class was chosen because the students have internalized the rudiments of the English Language to a large extent. Questionnaires were used for data collection. It deals with the demographic and socio-linguistic background of the students. There were fourteen (14) items designated to elicit the required information. The face and content validity of the instrument was ensured. A trial test of the instrument was carried out with students in Iworoko 
community senior secondary school, Iworoko-Ekiti, Ekiti State. A total of twenty-four students participated in the pilot programme. Split- half method was used and reliability coefficient of 0.9 was obtained. One way Analysis of Variance (ANOVA), t-test and Pearson Product Moment correlation statistics were employed for the data analysis.

\section{Results}

Test of hypothesis: Five research hypotheses were tested at 0.05 level of significance.

Hypothesis 1: Parents' occupation will not significantly impact on secondary school students' use of English.

Table 1. One-way ANOVA of parents' occupations and use of English.

\begin{tabular}{llllll}
\hline Between Groups & 259.04 & 8 & 32.38 & 5.81 & 1.94 \\
\hline Within Groups & 1286.94 & 231 & 5.57 & 5.81 & 1.94 \\
\hline Total & 1545.98 & 239 & & & \\
\hline
\end{tabular}

$\mathrm{P}<0.05$

Table 1 shows that Fcal (5.812) is greater than Ftable (1.94) at 0.05 level of significance. The null hypothesis is rejected. It implies that parents' occupations have significant impact on secondary school students' use of English.

Hypothesis 2: Gender will not significantly impact on secondary school students' use of English.

Table 2. t-test of gender and secondary school students' use of English.

\begin{tabular}{lllllll}
\hline Gender & $\mathrm{N}$ & Mean & SD & Df & t-cal & t-table \\
\hline Male & 132 & 19.24 & 2.68 & 238 & 0.05 & 1.96 \\
\hline Female & 108 & 19.25 & 2.38 & & & \\
\hline $\mathrm{p}>0.05$ & & & & & &
\end{tabular}

Table 2 shows that $\mathrm{t}$-cal $(0.045)$ is less than t-table (1.96) at 0.05 level of significance. The null hypothesis is accepted. Therefore, gender does not significantly impact on secondary school students' use of English.

Hypothesis 3: Students' class will not significantly impact on secondary school students' use of English.

Table 3. One-way ANOVA of class and secondary school students' use of English.

\begin{tabular}{llllll}
\hline Source & SS & DF & Ms & Fcal & Ftable \\
\hline Between Groups & 5.53 & & 2.77 & 0.43 & 2.99 \\
\hline Within Groups & 1540.45 & 237 & 6.50 & & \\
\hline Total & 1545.98 & 239 & & & \\
\hline
\end{tabular}

$\mathrm{p}>0.05$

Table 3 shows that Fcal (0.426) is less than Ftable (2.99) at 0.05 level of significance. Hence, the null hypothesis is accepted. Therefore, students' class will not significantly impact on secondary school students' use of English.

Hypothesis 4: Age of students will not significantly impact on their use of English language.

Table 4. Pearson's Correlation of age and secondary school students' use of English.

\begin{tabular}{llllll}
\hline Variable & $\mathrm{N}$ & Mean & SD & Rcal & Rtable \\
\hline Age & 240 & 15.19 & 1.50 & 0.08 & 0.19 \\
\hline Use of English & 240 & 19.24 & 2.54 & & \\
\hline $\mathrm{p}>0.05$ & & & &
\end{tabular}

Table 4 shows that $r$ cal $(0.079)$ is less than $r$ table $(0.195)$ at 0.05 level of significance. The null hypothesis is accepted. Hence, students' age does not significantly impact on secondary school students' use of English. 
Hypothesis 5: Religion will not significantly impact on secondary school students' use of English.

Table 5. t-test of religion and secondary school students' use of English.

\begin{tabular}{lllllll}
\hline Religion & $\mathrm{N}$ & Mean & SD & Df & Tcal & Ttable \\
\hline Christianity & 198 & 19.2424 & 2.54339 & 238 & 0.010 & 1.960 \\
\hline Islamic & 42 & 19.2381 & 2.57388 & 59.215 & &
\end{tabular}

$\mathrm{p}>0.05$

Table 5 shows that $\mathrm{T}$ cal of (0.010) is less than $\mathrm{T}$ table (1.960) at 0.05 level of significance. The null hypothesis is accepted. Therefore, religion does not significantly impact on secondary school students' use of English.

\section{Discussion}

The findings have revealed that parents' occupations have input on students' use of English. What this simply denotes is that parents who are educated and whose socio-economic status can be classified as middle or high are most probably speaking English at home and since the society is a microcosm of the large world, the effect will be conspicuously seen in their children performance. Parents should take advantage of this finding to speak, interact more often with these learners. These parents have been able to afford all educational materials; they have access to television, computers and other technological gadgets that could aid their language learning (Adeyemi and Kalane). These actions of parents are translated into adequate use in the classrooms. This findings support the view of Bamisaye (2006) that the middle class demonstrates an elaborate linguistic code, facilitating the verbal development of subjective intent and sensitivity to the implication of separateness and differences, providing a complex conceptual hierarchy for the restricted code of the lower working class is distinguished by the rigidity of its syntax. The place of the family in the language education of their children cannot be relegated to the background. It will remain a pivotal on which children can always learn and make great progress whether in language acquisition and development.

It was also revealed that gender and students' use of English has no strong relationship. The implication is that both male and female learners of English have equal chances of learning and acquiring tools of language. Both male and female students should strive and be encouraged to use English language at home and in classrooms. This finding corroborates that of Babalola (2010), Ofodu and Babatope (2010).

It was revealed that students' age does not significantly impact on secondary school students' use of English. One of the possible reasons for this result could be credited to the fact that these students are no longer so young. This supports the findings of Matsuoka and Smith (2008).

The study is a pointer to the fact religion has nothing to do with language acquisition and learning although religion is a major factor in education. Many school age children are sometimes deprive of education because of the belief that Western that would culminate in learning a second language. This attitude could either make or make such pupils. Religion is a tool of peace, stability and security. It should never decide how and what language learners learn especially the English language. Parents should give their wards free hands to learn whatever language they choose to learn.

\section{Conclusion and Recommendation}

It can be concluded from the findings of this study that mass failure of students in English language among secondary school students was not due to gender, age, religion but to other variables such as the learners' parents' occupation and socio-economic background. Therefore, it is very important for all parents to assist their wards by providing learning materials, time and other resources that could help their children's language skills. It is recommended that parents and all authorities concerned with the education of children should give adequate attention to the needs of children so that they can be their best while learning.

\section{References}

Adeyemi, D. A., \& Kalane, M. S. (2011). English in Botswana junior secondary curriculum. International Journal of Educational Sciences. Delhi: India.

Afe, Richard, \& Afe, Yinka. (2005). Modern trends in English. Akure: JV Educational Publisher.

Adegbile, J. A. (2002). Advance organizer and the secondary schoolteacher. In S. O. Ayodele (Ed), Teaching strategies for Nigerian secondary schools. Ibadan: Powerhouse Publishers.

Akinwanmide, T. K. (2012). The influence of process approach on English as Second Language students performances in essay writing. English Language Teaching, 5(3), 16-29. http://doi.org/10.5539/elt.v5n3p16

Babalola, J. O. (2010). Language and gender distinction. UNADJOE Journal of Education, 5(1), 124-133. 
Babatunde, J. O. (2008). Relative Effect of Demographic Variables on Motivation for Occupational Preference of Secondary School Students in Ekiti State. Nigerian Journal of Counseling and Applied Psychology.

Burman, D. D., Booth, J. R., \& Bitan, Tal. Boys' And Girls' Brains Are Different: Gender Differences In Language Appear biological. Science News Daily, March, 2008. Retrieved 22/4/2012, from, http://www.sciencedaily.com/releases/2008/03/080303120346.htm

Courrege, Diette. (2011). Reading Levels of Rural Students Worse Than Suburban Peers Retrieved 2/9/2011 Microsoft ${ }^{\circledR}$ Encarta ${ }^{\circledR}$ 2009. (C) 1993-2008 Microsoft Corporation. All rights reserved.

Ellis, R. (1994). The study of second language acquisition. OXFORD, NewYork: Oxford University Press.

Ilugbusi A. A., Falola E. O., \& Daramola M. A. (2007). Relative Effects of Demographic Variables on the levels of Anxiety of Integrated Science Trainee Teachers in Junior Secondary Schools in Ekiti State of Nigeria. Educational Focus.

Kolawole, C. O. O. (2005). The state of reading in some selected secondary schools in south-western Nigeria: preliminary report. In A Dada., A. Abimbade, \& C. O. O. Kolawole (Eds.), Issues in Language, Communication and Education. Ibadan: Constellation Books.

Eliot, Lise. (2011). Single-Sex Education and the Brain. Sex Roles, 2011. http://doi.org/10.1007/s11199-011-0037-y

Matsuoka R., \& Smith I., (2008). Age Effects in Second Language: Overview. J Nurs Studies NCNJ, 7(1). Retrieved from www.ncn.ac.jp/04_for_medical/kiyo/ar/2008jns-ncnj06.pdf

Melville, Kate (2006). Big Gender Differences In Language Learning. Georgetown University Medical Center. Retrieved April 21, 2012, from, http://www.temple.edu/tlc/research/publications/Pavlenko/Gender_and_English_Language_Learners\%20(P avlenko).pdf

Northwestern University. (2008, March 3). Boys' And Girls' Brains Are Different: Gender Differences In Language Appear Biological. Science Daily. Retrieved April 22, 2012, from, http://www.sciencedaily.com /releases/2008/03/080303120346.htm

Ofodu, G. O., \& Adeniyi, F. (2008). Impact of Personality and Environmental variables on Learners' Reading Abilities. Journal of Educational Foundations \& Management.

Ofodu, G. O. (2009). Comparative effects of two cooperative instructional methods on reading performance of secondary school students in Ekiti State, Nigeria. An Unpublished Ph.D Thesis, University of Ilorin, Nigeria.

Ofodu, G. O., \& Babatope, J. K. (2010). Diagnostic evaluation of segmental and suprasegmental skills of students of the federal polytechnic, Ado-Ekiti. UNADJOE Journal of Education, 5(1), 188-194.

Ofodu, G. O., \& Lawal, R. A. (2011, November). Gender parity and secondary school students' achievement in English comprehension. Proceedings of the London International Conference on Education (2011), 96-101. London, United Kingdom.

Omowa, Adepeju. (2012). Influence of sociolinguistics background on the teaching and learning of English in schools. An unpublished B.Ed Project, Ekiti State University.

Orifayo, J. O. (1999). The role of age in Understanding Mathematics. In C. T. O Akinmade, G. O. Akpa, \& T. O. Oyetunde (Eds), Primary Methods: A Guide to Effective Teaching. Jos: Conference on Educational Improvement.

Shuaibu U., \& Ahmed M. B. (2009). Implication of Gender Imbalance in the Teaching and Learning of English Language on the Achievement of the Millenium Development Goals (MDGs) in Nigeria. The Voice of Teachers, $1(1)$.

Springer. (2011, August 18). Review highlights flawed logic of segregating boys and girls for education purposes, based on alleged brain differences. Science Daily. Retrieved April 22, 2012, from, http://www.sciencedaily.com/releases/2011/08/110818101653.htm

Vygotsky, L. S. (1978). Mind and society: The development of higher psychological process. Cambridge: Harvard University Press.

http://esl.fis.edu

http://www.language-learning-advisor.com/age-and-language-learning.html 